\title{
A note on the nutritive value of roasted velvet bean (Mucuna pruriens) in broiler diets
}

\author{
S.A. Osei and A.B. Derkyi \\ Department of Animal Science, \\ Kwame Nkrumah University of Science and Technology \\ Kumasi, Ghana \\ (Received 15 January 2001; accepted 7 August 2001)
}

\begin{abstract}
The nutritive value of roasted Mucuna pruriens var, utilis (mucuna or velvet bean) was investigated in a four-week study using 336 mixed-sex three-week old broiler chickens. The birds were randomly allocated to four dietary treatments. Fifty, 100 or $150 \mathrm{~g}$ of mucuna beans, roasted in metal bowls over a wood-fired stove until they turned light brown was included into nutritionally balanced diets. Control diet did not contain mucuna beans. Feed and water were supplied ad libitum. Performance criteria studicd included fecd intake, growth rate, feed conversion ratio, carcass parameters and mortality.

Roasted mucuna beans at the levels of 50 and $100 \mathrm{~g} \mathrm{~kg}^{-1}$ significantly $(\mathrm{P}<0.05)$ improved the growth and feed utilization of broilers. At $150 \mathrm{~g} \mathrm{~kg}^{-1}$ dict, however, mucuna beans depressed weight gains and feed utilization.
\end{abstract}

KEY WORDS: Mucuna puriens, velvet bean, roasting, broiler performance

\section{INTRODUCTION}

Mucuna puriens var. utilis (mucuna or velvet bean; MP) has been grown from time immemorial in Ghana and other countries as a component of the traditional crop farming systcm. Among various Ghanaian tribes, the beans find use in the preparation of soups and stews (Ahenkora et al., 1994, unpublished). In recent years mucuna has gained popular acceptance among farmers as a cover crop helping to control weeds and also improve soil fertility by fixing nitrogen (Osei-Bonsu and Buckles, 1993; Buckles, 1995). The large-scale cultivation of mucuna has meant that large quantities of the beans are left un-utilized as human food. The dry 
matter of velvet beans MP contains $250 \mathrm{~g} \mathrm{~kg}^{-1}$ protein (Ahenkora et al., 1999) and this makes MP attractive as a potential feed ingredient for poultry that may serve as a replacement (at least partially) for more expensive protein ingredients like fish meal and soyabean meal. There is little published literature in this regard although work using raw MP showed deleterious effects on chick and broiler performance (Vieira and Carvalho, 1996; Osci and Dei, 1998, unpublished). The negative effects of MP have been variously attributed to the presence of toxic antinutritional factors including anti-trypsin factors, tannins, phytic acid, L-DOPA, anticoagulants and others (Liener and Kakade, 1969; Sathe and Salunke, 1984; Ravindran and Ravindran, 1988; Osei-Bonsu and Buckles, 1993; Houghton and Skari, 1994). Several heat treatments have been employed to destroy anti-nutrients in various leguminous seeds (Huisman and Tolman, 1992).

This work was undertaken to investigate the beneficial effects of roasting on the nutritive value of Mucuna pruriens for broiler chickens.

\section{MATERIAL AND METHODS}

Dried mature mucuna beans (MP) were obtained either from local farmers growing the crop under a Sasakawa Global 2000-sponsored pilot project or from test plots of the Crops Research Institute, Kumasi (Ghana). The beans were roasted in quantities of approximately $1 \mathrm{~kg}$ for approximately $20 \mathrm{~min}$ in metal bowls over wood-fired stoves until they turned light brown. They were then milled through a $3 \mathrm{~mm}$ sieve in a hammermill. The milled beans were analysed for proximate constituents using conventional methods (AOAC, 1980).

Three hundred and thirty six mixed-sex Shaver Tropicbro commercial broiler chickens (Pomadze Poultry Enterprises, Winneba, Ghana) aged 21 days old were initially weighed in groups to obtain the mean weight for the flock. They were then individually weighed and re-allotted in equal numbers to four experimental dietary groups such that the groups were equalized for sex and weight. The control diet was formulated as a combined starter-finisher diet containing approximately $210 \mathrm{~g} \mathrm{~kg}^{-1}$ crude protein; the three other test diets contained 50,100 and $150 \mathrm{~g}$ mucuna per kg, respectively, replacing equal amounts of the control diet (Table 1). The diets were isocaloric and isonitrogenous.

The trial was conducted according to the completely randomised design and each treatment had three replicates. The experimental broilers were reared in raised wire floor coops with floor space averaging approximately $0.14 \mathrm{~m}^{2}$. Feed and water were supplied ad libitum. The trial lasted 28 days.

The following parameters were measured: feed intake, liveweight gain, feed conversion ratio and mortality. On the final day of the trial, three broilers were selected randomly from each treatment replicate and slaughtered for carcass analysis. 
TABLE 1

Composition and nutrient content of experimental diets, $\mathrm{g} \mathrm{kg}^{-1} \mathrm{DM}$ except ME

\begin{tabular}{lcccc}
\hline \multirow{2}{*}{ Ingredient } & \multicolumn{4}{c}{ Level of mucuna beans g kg.1 } \\
\cline { 2 - 5 } & 0 & 50 & 100 & 150 \\
\hline Mucuna beans & 0 & 50 & 100 & 150 \\
Maize & 600 & 600 & 600 & 600 \\
Fish meal & 110 & 100 & 90 & 80 \\
Soyabean meal & 150 & 150 & 150 & 140 \\
Wheat bran & 110 & 70 & 30 & 0 \\
Constant components' & 30 & 30 & 30 & 30 \\
& & & & \\
Calculated analysis & & & 108 & 206 \\
crude protein & 209 & 208 & 11.45 & 11.56 \\
ME (MJkg') & 11.50 & 11.49 & 44.2 & 45.6 \\
ether extract & 42.5 & 43.6 & 45.7 & 43.0 \\
crude fibre & 49.7 & 48.4 & 6.5 & 6.6 \\
methionine + cystinc $^{2}$ & 7.2 & 7.3 & 8.3 & 8.3 \\
lysine & 8.7 & 8.4 & 1.9 & 9.8 \\
tryptophan & 1.7 & 1.6 & 10.0 & 5.40 \\
Ca & 10.6 & 10.5 & 5.53 & \\
P, available & 5.92 & 5.78 & & \\
\hline
\end{tabular}

' providing per $1 \mathrm{~kg}$ diet: $(\mathrm{g})$ oyster shell 10; dicalcium phosphate $10 ; \mathrm{NaCl} 5$; vitamin-mineral premix 5, supplying per kg of diet; vit. A, $20000 \mathrm{IU}$; $\mathrm{D}_{3}, 4000 \mathrm{IU} ; \mathrm{E}, 30 \mathrm{IU} ; \mathrm{K}, 2 \mathrm{IU}$ (mg) $\mathrm{B}_{1}, 2$; $\mathrm{B}_{2}$, 9; $\mathrm{B}_{12}, 0.024$; niacin, 50: Fe, 90; Cu, 5; Mn, 120: Co, 1; I, 4; Se, 0.4

2 amino acid content of mucuna from Achinewhu (1982)

The analysis of variance was used in data analysis while significant differences among treatment means were estimated using Fisher's least significant difference test (Steel and Torrie, 1980).

\section{RESULTS AND DISCUSSION}

Proximate analysis showed that roasted velvet beans contained $92.8 \mathrm{~g} \mathrm{~kg}^{-1} \mathrm{dry}$ matter which in turn contained per $\mathrm{kg} / \mathrm{g}$ : crude protein, 246; crude fibre, 65.4; ether extract, 52.0; ash 32.0; and $\mathrm{N}$-free extractives, 604.6. These values are in close agreement with those presented by Osci and Dei (1998, unpublished) and Dei Carmen et al. (1999) and indicate that heating may generally slightly increase nutricnt values as a result of the evaporation of water (Ahenkora et al., 1999). The crude protein content of MP compares favourably with that of chickpea, mung bean and several cowpea varieties (Hsu et al., 1977; Abbey and Ibeh, 1988). 
The effects of roasted velvet beans on broiler performance are summarized in Table 2. Roasted MP at 50 or $100 \mathrm{~g} \mathrm{~kg}^{-1}$ diet significantly improved weight gains (2-4\%) and feed conversion ratio (1.2-3.4\%) over the control diet. At the $150 \mathrm{~g} \mathrm{~kg}^{-1}$ diet level, however, MP significantly depressed weight gain $(3.3 \%)$ and efficiency of feed utilization $(6.7 \%)$ compared with the control. The depression in weight

TABLE 2

Performance of broilers

\begin{tabular}{lccccc}
\hline \multirow{2}{*}{ Parameter } & \multicolumn{3}{c}{ Dictary level of mucuna beans, $\mathrm{g} \mathrm{kg}^{-1}$} & Overall \\
\cline { 2 - 5 } & 0 & 50 & 100 & 150 & SEM \\
\hline Initial body weight, $\mathrm{g}$ & 480 & 480 & 480 & 480 & - \\
Final body weight, $\mathrm{g}$ & $1920^{\mathrm{b}}$ & $195 \mathrm{I}^{\mathrm{a}}$ & $1980^{\mathrm{a}}$ & $1873^{\mathrm{a}}$ & 48.7 \\
Body weight gain, $\mathrm{g}$ & $1440^{\mathrm{b}}$ & $1471^{\mathrm{a}}$ & $1500^{\mathrm{a}}$ & $1393^{\mathrm{a}}$ & 48.5 \\
Total feed intake, $\mathrm{g}$ & 3251 & 3270 & 3287 & 3270 & 35.6 \\
Feed: gain ratio & $2.25^{\mathrm{a}}$ & $2.22^{\mathrm{a}}$ & $2.19^{\mathrm{b}}$ & $2.35^{\mathrm{c}}$ & 0.02 \\
Mortality, \% & 2.4 & 2.4 & 0 & 3.6 & - \\
\hline
\end{tabular}

a,b.e $\mathrm{P}<0.05$

gain was evident by the end of the second week while impaired feed utilization efficiency was observed at the end of the third week. Del Carmen et al. (1999) have reported that heated MP when fed at $10 \%$ of the diet had deleterious effects only early weight gain while 20 and $30 \%$ heated MP progressively depressed weight gain and efficiency of feed utilization in a 42-day feeding trial. In an earlier trial, Osei and Dei (1998, unpublished) all levels of raw MP from 5 to $15 \%$ of the diet caused significant deterioration in broiler chicken performance. It is suggested that heating in this trial might have destroyed or inactivated anti-nutritional factors present in unheated MP making it possible to include up to $100 \mathrm{~g} \mathrm{~kg}^{-1}$ in broiler diets. Data from Del Carmen et al. (1999) indicates that heat treatment destroyed anti-trypsin activity without affecting L-DOPA. Whether heating affected any other factor is not clear since these were not studied. The depressive effect of the $150 \mathrm{~g} \mathrm{~kg}^{-1} \mathrm{MP}$ on broiler performance is difficult to explain. It is possible that other thermostable factors were involved. Ahenkora et al. (1999) have stated that the majority of toxic effects reported in human consumption of MP bean preparations are attributable to L-DOPA.

There were no significant dietary treatment effects on feed consumption, mortality and carcass dressing percentage. Del Carmen et al. (1999) observed significant decreases in feed consumption only in broiler chickens fed diets containing 20 or $30 \% \mathrm{MP}$. The highest level of MP in this trial was only $150 \mathrm{~g} \mathrm{~kg}^{-1}$. The lack of significant effect of MP on mortality and carcass weights agrees with other reports (Osei and Dei, 1998, unpublished; Del Carmen et al., 1999). 
Table 3 shows the effects of dietary mucuna on various organ weights. No significant effects on the kidney weight were evident from feeding MP. On the other hand, there were significant depressions in the weights of gizzard, liver and small intestine at all levels of MP incorporation. MP at $150 \mathrm{~g} \mathrm{~kg}^{-1}$ diet exerted the most serious effects. The authors are not aware of work with MP in which organ weights were studied. Most work on antinutritional factors has in fact concentrated on physiological changes (Huisman and Tolman, 1992).

The results of this study show that roasting can improve the nutritive value of MP and permit its incorporation into broiler diets up to $10 \%$. It is however possible that if all the toxic/antinutritional factors were removed it might be possible to include higher levels of MP in broiler diets. A variety of detoxification methods including particurarly boiling and soaking have been employed to make MP beans safe for human consumption. Studies of processing technologies and treatments for improving the nutritive value of MP for chickens are recommended.

TABLE 3

Carcass parameters, liveweight $\%$

\begin{tabular}{lccccc}
\hline \multirow{2}{*}{ Parameter } & \multicolumn{3}{c}{ Dietary leve! of mucuna beans, g kg-1 } & Overall \\
\cline { 2 - 5 } & 0 & 50 & 100 & 150 & SEM \\
\hline Dressing percentage & 76.7 & 74.9 & 77.0 & 77.2 & 2.36 \\
Heart & $0.87^{\mathrm{b}}$ & $1.22^{\mathrm{a}}$ & $1.14^{\mathrm{a}}$ & $1.25^{\mathrm{a}}$ & 0.21 \\
Kidney & 0.76 & $0.67^{\mathrm{a}}$ & 0.63 & 0.65 & 0.06 \\
Small intestine & $1.70^{\mathrm{a}}$ & $0.92^{\mathrm{b}}$ & $0.92^{\mathrm{b}}$ & $1.21^{\mathrm{a}}$ & 0.05 \\
Liver & 3.78 & 2.70 & 2.76 & 2.98 & 0.25 \\
Gizzard & $1.74^{\mathrm{a}}$ & $1.07^{\mathrm{a}}$ & $0.88^{\mathrm{b}}$ & $0.73^{\mathrm{b}}$ & 0.16 \\
\hline
\end{tabular}

a.b.c. different at $\mathrm{P}<0.05$

\section{ACKNOWLEDEMENT}

The authors are grateful to the Ghana Office of Sasakawa Global 2000 for providing the mucuna beans for the trial.

\section{REFERENCES}

Abbey B.W., lbeh G.O., 1988. Functional properties of raw and heat processed cowpea Vigna unguiculata flour. J. Food Sci. 53, 1775-1777

Ahenkora K., Dadzic M., Osei-Bonsu P., 1999. Composition and functional properties of raw and heat processed velvet bean (Mucuna pruriens L. DC. var. utilis) flours. Int. J. Food Sci. Tech. $34,131-135$ 
AOAC, 1984. Official Methods of Analysis. Association of Official Analytical Chemists. 15th Edition. Washington, DC

Buckles D., 1995. Velvet bean: a "new" plant with a history. Econ. Bot. 49, 13-25

Del Carmen J., Gernat A.G., Myrhman R., Carew L.B., 1999. Evaluation of raw and heated velvet beans (Mucuna pruriens) as feed ingredients for broilers. Poultry Sci. 78, 866-872

Liener I.E., Kakade M.L., 1969. Protease inhibition: In: I.E. Liener (Editor). Toxic Constituents of Plant Foodstuffs. Academic Press, New York

Houghton P.J., Skari K.P., 1999. The effect on blood clotting of some West African plants used against snakebite. J. Ethnopharmacol. 44, 99-108

Hsu H.W., Vavak D.L., Satferlee L.D., Miller G.A., 1977. A multienzyme technique for estimating protein digestibility. J. Food Sci. 42, 1269-1271

Huisman, J., Tolman, G.H., 1992. Antinutritional factors in the plant proteins of diets for nonruminants. In: P.C. Garnsworthy, W. Haresign, D.J.A. Cole (Editors). Recent Advances in Animal Nutrition. Butterworth-Heinemann Ltd., Oxford, pp. 3-31

Osei-Bonsu, Buckles P., 1993. Controlling weeds and improving soil fertility through the use of cover crops: experience with Mucuna spp. in Benin and Ghana. WAFSRN Bull. 14, 2-7

Ravindran V., Ravindran G., 1988. Nutritional and anti-nutritional characteristics of mucuna (Mucuna wilis) bean seeds. J. Sci. Food Agr. 46, 71-79

Sathe S.K., Salunke D.K., 1984. Technology of removal of unwanted components of dry beans. CRC Critical Rev. Food Sci. Nutr. 21, 263-286

Steel R.G.D., Torrie J.H., 1980. Principles and Procedures of Statisties: a Biometrical Approach. 2nd Edition. McGraw Hill, New York

Vieira R.D., Carvalho N.M., 1996. Velvet bean (Mucuna spp.j. In: E. Nwokolo, J. Smartt (Editors). Food and Feed from Legumes and Oilseeds. Chapman and Hall, New York

\section{STRESZCZENIE}

\section{Wartość pokarmowa prażonego aksamitnego bobu dla kurcząt brojlerów}

Wartość pokarmową prażonego aksamitnego bobu oznaczono w 4-tygodniowym doświadezeniu na 336 trzytygodniowych kurczętach brojlerach obydwóch płci. Kurczęta podzielono losowo na 4 grupy żywieniowe. Pięćdziesiąt, 100 lub $150 \mathrm{~g}$ bobu, prażonego $\mathrm{w}$ metalowych naczyniach, w piecach ogrzewanych drewnem, aż do uzyskania jasno - brązowego koloru, włączano do zbilansowanych diet. Dieta grupy kontrolnej nie zawierała bobu. Pasza i woda były podawane do woli. Oznaczano pobranje paszy, przyrosty i wykorzystanie paszy, śmiertelność oraz niektóre wskaźniki tuszy.

Udział w dietach bobu aksamitnego w ilości 50 i $100 \mathrm{~g} \mathrm{~kg}^{-1}$ istotnie $(\mathrm{P}<0,05)$ poprawiał przyrosty i wykorzystanie paszy; dawka 150 g pogarszała te wskaźniki. 